\title{
In vitro the behaviors of metastasis with suppression of VEGF in human bone metastatic LNCaP-derivative C4-2B prostate cancer cell line
}

\author{
Lei Yang ${ }^{1}$, Shuo You $^{2}$, Vikas Kumar ${ }^{3}$, Chaoyue Zhang ${ }^{1}$ and Ya Cao ${ }^{4^{*}}$
}

\begin{abstract}
Background: Vascular endothelial growth factor (VEGF) is a signal protein produced by cells that stimulates vasculogenesis and angiogenesis. VEGF is believed to implicate poor prognosis in various cancers. The overexpression of VEGF may be an early step in the process of metastasis.

Methods: ELISA was used to investigate the levels of VEGF, bFGF and IL8 in human bone metastatic LNCaP-derivative C4-2B prostate cancer cell line and its parental cell line, LNCaP and to determine the effect of bevacizumab on reducing the level of VEGF. Cell proliferation assay, invasion assay and in vitro angiogenesis assay were performed under the condition with bevacizumab or control lgG.

Results: Human bone metastatic LNCaP-derivative C4-2B prostate cancer cell line expressed a higher level of VEGF than its parental primary prostate cancer cell line LNCaP. The effect of bevacizumab is dose-dependent and time-dependent: $100 \mathrm{\mu g} / \mathrm{mL}$ of bevacizumab and 3-day treatment was more effective than low-dose and lesser-day treatment for decreasing the level of VEGF. Bevacizumab is able to suppress cell proliferation, angiogenesis and invasion in human bone metastatic C4-2B prostatic cancer cell line.
\end{abstract}

Conclusions: The overexpression of VEGF can be inhibited by bevacizumab in human bone metastatic cancer cell line. The behaviors of metastasis involving proliferation, angiogenesis and invasion are suppressed by anti-VEGF therapy.

Keywords: Metastasis, Bone, Prostate cancer, VEGF

\section{Background}

Most of the time, when patients have cancer in their bones, it is caused by metastatic cancer, or cancer that has spread from elsewhere in the body to the bones. It is much less common to have a primary bone cancer that arises from cells that make up the bone. Surgery, chemotherapy and radiation therapy are the three main types of treatment for bone cancer. Unfortunately, there are risks and side effects associated with each of the treatments for bone cancer. The main risks associated with surgery include infection, recurrence of the cancer, and injury to the surrounding tissues that may cause loss of sensation, strength or function, or even cause amputation. The medications of chemotherapy are designed to kill rapidly

\footnotetext{
* Correspondence: ycao98@vip.sina.com

${ }^{4}$ Cancer Research Institute of Xiangya School of Medicine, Central South University, Changsha, Hunan 410078, China

Full list of author information is available at the end of the article
}

dividing or growing cells, but unfortunately normal cells are also adversely affected. Radiation therapy damages the surrounding skin and soft tissue and impairs wound healing. There has been much recent advancement in the understanding and treatment of bone cancer. This has led to more focused radiation therapy to reduce the risk to surrounding tissues, less side effects, and improved treatment options, including limb-salvaging surgery, that decrease the need for amputation. There is currently much work being conducted in each of these areas as well as investigations into the mechanisms of development of metastatic cancer. It is hoped that a better understanding of specific causes and mechanisms of metastatic cancer will lead to advanced therapy that targets specific metastatic cancer cells with limited risk to other normal cells.

Tumors are able to grow independently of vascularization until they reach a size of approximately $2 \mathrm{~mm}$. At this size
C Biomed Central

(c) 2012 Yang et al.; licensee BioMed Central Ltd. This is an Open Access article distributed under the terms of the Creative Commons Attribution License (http://creativecommons.org/licenses/by/2.0), which permits unrestricted use, distribution, and reproduction in any medium, provided the original work is properly cited. 
the tumor is unable to grow further due to the lack of nutrients and gas exchange, resulting in tumor dormancy [1]. Continued growth requires tumor vascularization. Cancer cells are able to induce angiogenesis by secreting angiogenic factors including vascular endothelial growth factor (VEGF) in order to activate certain actions by endothelial cells [2]. Normally, endothelial cells divide infrequently, being held in check by angiogenesis inhibitors. Once activated the endothelial cells secrete matrix-metalloproteases which begin to digest the extracellular matrix surrounding the blood vessels. The endothelial cells can then remodel the tissue. These migrating cells also divide and increase in number, eventually organizing into discrete tubules. Eventually these tubules connect via anastomosis to form the neovasculature of the tumor. The up-regulated VEGF promotes the activation of matrix-metalloproteases [3-5]. We hypothesize that an anti-VEGF agent is able to maintain tumor dormancy, and we aim to prove this hypothesis using in vitro cell growth assay, angiogenesis assay and invasion assay. For solid tumors, such as prostate cancer, breast cancer and lung cancer, there is the chance that the cancer will become advanced and spread to the bone. In fact, for prostate cancer the bone is the most common site of recurrence: approximately $80 \%$ of prostate cancer recurrences are in the bone [6]. In this study, we will report how anti-VEGF therapy affects the growth and invasion of the bone metastatic prostate cancer cell.

\section{Materials and methods}

\section{Cell culture and reagents}

Human bone metastatic prostate cancer $\mathrm{C} 4-2 \mathrm{~B}$ cell line is a derivative of the $\mathrm{LNCaP}$ prostate cancer cell line with androgen-independent characteristics. C4-2B cells were obtained from ViroMed Laboratories, and LNCaP cells were purchased from American Type Culture Collection (Manassas, VA). Both C4-2B and LNCaP cells were maintained as monolayer cultures in RPMI 1640 medium supplemented with $2 \mathrm{mM} \mathrm{L}$-glutamine, 10\% fetal bovine serum and penicillin-streptomycin in a humidified atmosphere of $5 \% \mathrm{CO}_{2}$ at $37^{\circ} \mathrm{C}$. Human microvessel cells (VEC Technologies company, Rensselaer, New York) were cultured in endothelial cell growth medium (PromoCell, Heidelberg, Germany) in a humidified atmosphere of $5 \% \mathrm{CO}_{2}$ at $37^{\circ} \mathrm{C}$.

Bevacizumab (Genentech, San Francisco, CA) is a recombinant humanized monoclonal IgG1 antibody that contains human framework regions and the complementarity-determining regions of a murine antibody that binds to and inactivates all isoforms of VEGF.

\section{VEGF, bFGF and IL-8 ELISA assays}

The secretion of VEGF, basic fibroblast growth factor (bFGF) and interleukin 8 (IL-8) by C4-2B cells to culture medium was quantified by an enzyme-linked immunosorbent assay (ELISA). A density of $2 \times 10^{5}$ of C4-2B, $\mathrm{LNCaP}$ and human microvessel cells were separately plated in a six-well plate. Human bone metastatic prostate cancer C4-2B cells were also co-cultured with human microvessel cells. All cultures were performed in triplicate. When the cells reached $90 \%$ confluence on the third day after they were seeded, the media were changed to complete culture media with 25 or $250 \mu \mathrm{g} / \mathrm{mL}$ bevacizumab, or an equal amount of IgG1. The cell culture media were collected at 72 hours after treatment in culture medium with $2 \% \mathrm{FBS}$ in $5 \% \mathrm{CO}_{2}$ at $37^{\circ} \mathrm{C}$. The levels of VEGF, bFGF and IL-8 in the supernatants were measured with an ELISA kit (Quantikine; R\&D Systems, Minneapolis, $\mathrm{MN}$ ) according to the manufacturer's instructions.

\section{Cell proliferation assay}

A density of $5 \times 10^{3}$ cells per well was seeded on 96well-plate overnight in complete culture medium and then treated with bevacizumab or control IgG or recombinant human VEGF in complete culture medium without fetal bovine serum for a 3-day incubation. The cell numbers were measured every 24 hours by mitochondrial 3-(4,5-dimethylthiazol-2-yl)-5-(3-carboxymethoxyphenyl)-2-(4-sulfophenyl)-2 H-tetrazolium, inner salt (MTS) assay with use of the CellTiter 96 Aqueous One Solution Cell Proliferation Assay (Promega) according to the manufacturer's instructions.

\section{Invasion assay}

When C4-2B cells reached below $80 \%$ confluence, serum containing medium was removed and replaced with serum-free medium containing bevacizumab $(100 \mu \mathrm{g} /$ $\mathrm{mL}$ ) or an equal amount of IgG, and cultures were returned to an incubator for 24 hours. The in vitro invasion assay was performed with a 24-well collagen-based cell invasion assay kit (Millipore). $2 \times 10^{5}$ of C4-2B cells in $300 \mu \mathrm{l}$ culture medium containing $100 \mu \mathrm{g} / \mathrm{ml}$ bevacizumab or IgG were placed into an invasion chamber consisting of a 24-well collagen-based plate. In order to observe the direct role of VEGF on the invasion of C42B cells, recombinant human VEGF (100 ng/ml) was added to the lower chamber. The cells were incubated for $24 \mathrm{~h}$ at $37^{\circ} \mathrm{C}$ in a $5 \% \mathrm{CO}_{2}$ incubator. The noninvading cells in the media were discarded from the top of the insert. The invasive cells on the lower surface of the membrane were stained by the green fluorescent dye Calcein AM (Invitrogen) in $\mathrm{PBS}$ at $37^{\circ} \mathrm{C}$ for $1 \mathrm{~h}$. The fluorescently labeled cells were photographed under a fluorescence microscope. The fluorescence of the invaded cells was read by a microplate reader at excitation/emission wavelength of 530/590 nm. 


\section{In vitro angiogenesis assay}

When C4-2B cells reach $80 \%$ confluence, they were cultured in serum-free RPMI1640 treated with bevacizumab $(100 \mu \mathrm{g} / \mathrm{mL})$ or an equal amount of $\operatorname{IgG}$ for $24 \mathrm{~h}$. The conditioned media were collected, centrifuged, and transferred to fresh tubes. Human microvessel cells were maintained in complete media and starved for $4 \mathrm{~h}$, were trypsinized and seeded in each well with conditioned culture medium from C4-2B with $100 \mu \mathrm{g} / \mathrm{mL}$ bevacizumab or an equal amount of IgG1 on growth factor-containing ECMatrixgel (Millipore, Billerica, MA) in a 24well-plate, incubated in $5 \% \mathrm{CO}_{2}$ at $37^{\circ} \mathrm{C}$ for 10 hours, and inspected for tube formation with an inverted light microscope (Olympus, Tokyo, Japan). Three random fields per well were examined at $40 \times$ magnification, and the values were averaged. The pattern/value association criteria for tube formation are: 0 , individual cells, well separated; 1 , cells beginning to migrate and align themselves; 2, capillary tubes visible without sprouting; 3, sprouting of new capillary tubes; 4 , closed polygons beginning to form; and 5, complex meshlikestructures developing. Each well was photographed using an inverted microscope with a digital camera. The images were taken at $10 \times$ magnification and the total lengths of the tubes were measured with Image J (Image Processing Analysis in Java, ver. 1.42; developed by Wayne Rasband, National Institutes of Health, Bethesda, MD; available at http://rsb.info.nih.gov/ij/index.html).

\section{Statistical analysis}

Comparison between the two groups was performed using the student's $t$-test. A P value of less than 0.05 was considered significant and a $\mathrm{P}$ value of less than 0.01 was considered highly significant. Microsoft ${ }^{\circ}$ Office Excel 2003 SP3 was used for data analysis.

\section{Results}

\section{Expression of VEGF, bFGF and IL-8}

To screen for the expression of angiogenic factors in prostate cancer cell and its bone metastatic cell, three angiogenic factors in conditioned media were detected with ELISA. The secreted VEGF by the parental LNCap cell line and its derived bone metastatic cell line $\mathrm{C} 4-2 \mathrm{~B}$ was detected. The production of bone metastastic cell line C4-2B $\quad(294.47 \pm 31.99 \mathrm{pg} / \mathrm{ml})$ was significantly higher than its parental cell line LNCap (204.40 \pm $23.32 \mathrm{pg} / \mathrm{ml}, \mathrm{P}=0.016)$. The secreted $\mathrm{bFGF}$ and IL-8 protein were not detected in bone metastatic cell line C4-2B and its paretental LNCap cell line by EILSA.

\section{Bevacizumab suppressed VEGF from C4-2B and microvessel cells}

To determine the concentration of bevacizumab needed for neutralizing the secreted VEGF by bone metastatic prostate cancer C4-2B cell line, ELISAs were performed to measure the levels of VEGF in conditioned media in C4-2B and C4-2B co-cultured with microvessel cells under bevacizumab or control IgG treatment. The level of VEGF from cells with bevacizumab or control IgG treatment is shown in Figure 1. The level of VEGF secreted by human bone metastatic prostate cancer C4-2B cell line co-cultured with microvessel cells was much greater than that secreted by $\mathrm{C} 4-2 \mathrm{~B}$ only. Both 10 and $100 \mu \mathrm{g} / \mathrm{ml}$ bevacizumab decreased the level of VEGF secreted by C4-2B, compared with control IgG. There were significant differences in the VEGF levels between the 10 or $100 \mathrm{ug} / \mathrm{ml}$ bevacizumab and control IgG $(\mathrm{P}<0.01)$. Treatment with $100 \mu \mathrm{g} / \mathrm{ml}$ bevacizumab caused a more pronounced decreased in VEGF than treatment with $10 \mu \mathrm{g} / \mathrm{ml}$ bevacizumab. The level of VEGF was significantly increased when tumor cells were co-cultured with vascular endothelium. The levels of VEGF in co-culture media were 5.97 times greater than that in medium from C4-2B only. VEGF was reduced in $\mathrm{C} 4-2 \mathrm{~B}$ to $187.53 \pm$ $23.79 \mathrm{pg} / \mathrm{mlafter}$ treatment with $10 \mu \mathrm{g} / \mathrm{ml}$ bevacizumab and $91.06 \pm 19.82 \mathrm{pg} / \mathrm{ml}$ after treatment with $100 \mu \mathrm{g} / \mathrm{ml}$ bevacizumab, and in $\mathrm{C} 4-2 \mathrm{~B}$ co-cultured with microvessel cell VEGF was reduced to $949.42 \pm 177.88 \mathrm{pg} / \mathrm{ml}$ after treatment with $10 \mu \mathrm{g} / \mathrm{ml}$ bevacizumab and $297.20 \pm$ $69.27 \mathrm{pg} / \mathrm{ml}$ after treatment with $100 \mu \mathrm{g} / \mathrm{ml}$ bevacizumab,. There were significant differences in the VEGF levels between the 10 and $100 \mu \mathrm{g} / \mathrm{ml}$ bevacizumab

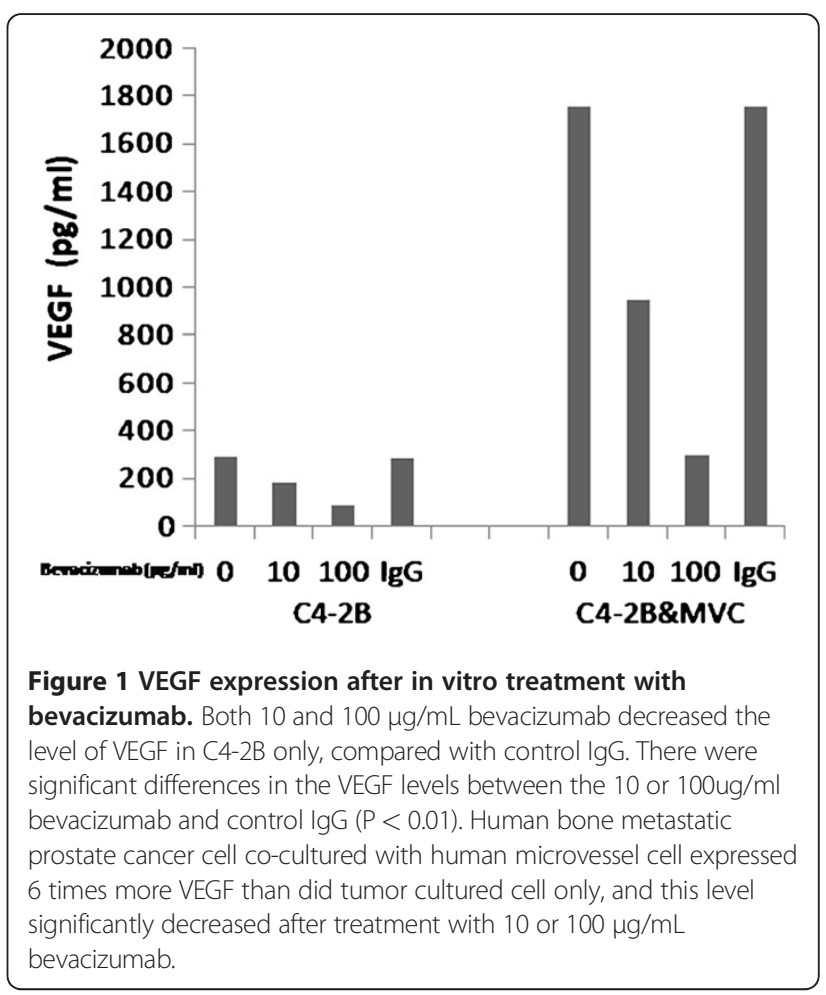


treatment cells and control IgG treatment cells $(\mathrm{P}<0.01$, Figure 1). A high concentration of bevacizumab was more effective than a low concentration on reducing VEGF in C4-2B cells and C4-2B cells co-cultured with microvessel cells.

\section{Bevacizumab inhibited cell proliferation in C4-2B}

Because the increased production of VEGF drives angiogenesis related to tumor progression, we investigate the possibility that neutralization of VEGF may interrupt by the growth of bone metastatic prostate cancer $\mathrm{C} 4-2 \mathrm{~B}$ cell line. When $\mathrm{C} 4-2 \mathrm{~B}$ cells were exposed to bevacizumab $(0,10,100 \mu \mathrm{g} / \mathrm{ml})$ for a 2-day incubation, the growth of $\mathrm{C} 4-2 \mathrm{~B}$ was inhibited in a concentrationdependent manner, whereas the control IgG did not affect the growth C4-2B cells, and VEGF enhanced the proliferation of $\mathrm{C} 4-2 \mathrm{~B}$ cells (Figure 2a). At day 3 bevacizumab $(100 \mu \mathrm{g} / \mathrm{ml})$ inhibited the proliferation of C4-2B cells by $83 \%$ (Figure 2b). These data suggest that bevacizumab significantly inhibited cell proliferation in bone metastatic prostate cancer cells.

\section{Bevacizumab suppressed of angiogenesis in vitro}

Based on the effect of different concentrations of bevacizumab on the proliferation in C4-2B cells, $100 \mu \mathrm{g} / \mathrm{ml}$ of bevacizumab would be used in the angiogenesis and invasion assay in vitro. Human microvessel cells developed complex meshlike structure patterns (grade 5) when grown in a growth-factor gel matrix. At 10 hour after control IgG treatment, the cells formed complex meshlike structure patterns (Figure 3, left). After treatment with bevacizumab $(100 \mu \mathrm{g} / \mathrm{ml})$, the cells showed a migration/alignment pattern (grade 1, Figure 3, right). The average total capillary tube length in human microvessel cells with IgG, or bevacizumab $(100 \mu \mathrm{g} / \mathrm{ml})$ was $1255.31 \pm 134.90$ and $195.04 \pm 26.67 \mu \mathrm{m}$, respectively $(\mathrm{P}<0.01)$.

\section{Bevacizumab reduced C4-2B cell invasion}

The level of VEGF is known to correlate with prostate cancer invasion and metastasis in bone. We performed in vitro invasion assay to estimate whether bevacizumab reduced C4-2B cell invasion. RPMI-1640 without FBS

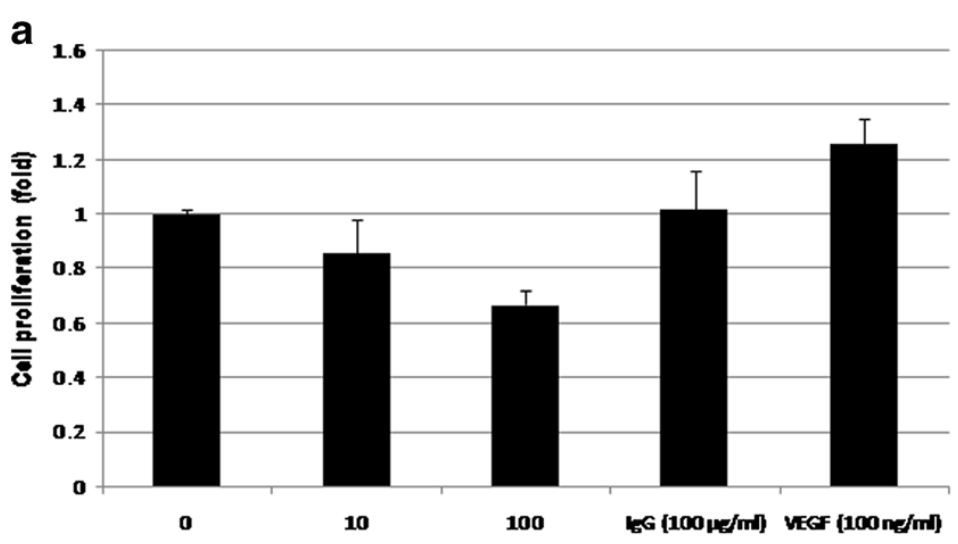

b

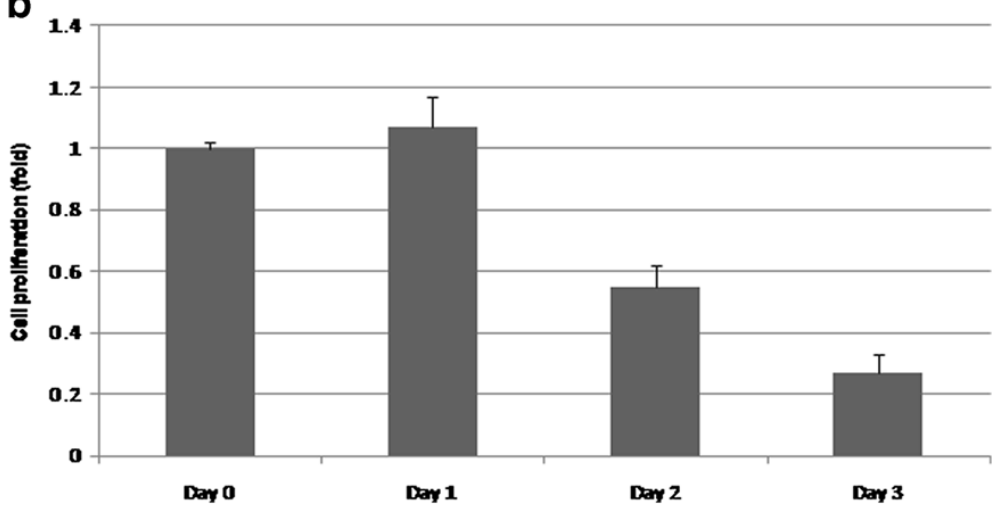

Figure 2 Bevacizumab inhibits the growth of bone metastasis prostate cancer cell line C4-2B. $\mathbf{a}$. Different concentrations of bevacizumab inhibited the cell proliferation of C4-2B in a dose-dependent manner after 2-day incubation determined by mitochondrial MTS assay. Ig G $(100 \mathrm{\mu g} / \mathrm{ml})$ did not decrease the growth of C4-2B. cells. VEGF $(100 \mathrm{ng} / \mathrm{ml})$ enhanced the growth of C4-2B cells. b. The effect of bevacizumab on the inhibitory proliferation of $\mathrm{C} 4-2 \mathrm{~B}$ was gradually increased with a time-dependence. The relative fold was assigned as 1.0 in the absence of bevacizumab treatment. ${ }^{* *}$ means $P<0.01$, significant differences from the bevacizumab treated with untreated group. 


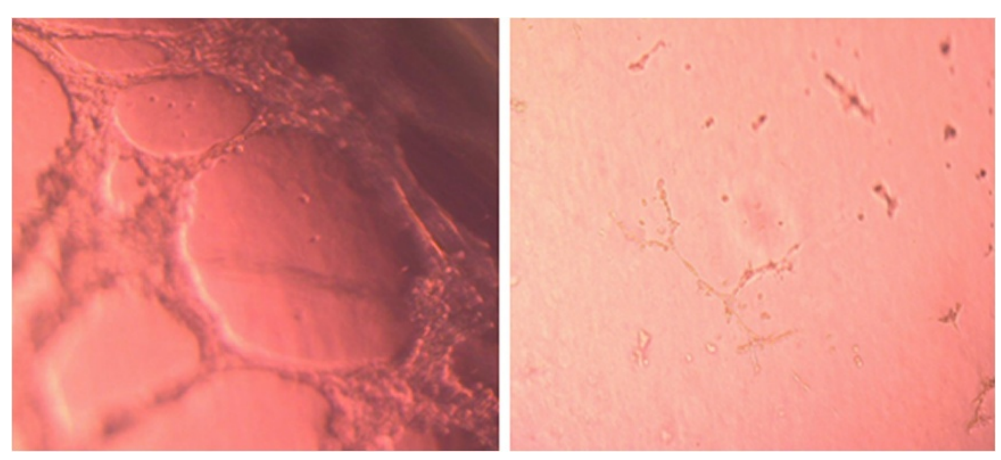

Figure 3 Suppressed tube formation of human microvessel by conditioned media from C4-2B cells treated with bevacizumab (right) or control lgG (left).

was added to the lower chamber as a negative background control, RPMI-1640 with 5\%FBS was added to the lower chamber and $\mathrm{C} 4-2 \mathrm{~B}$ cells without treatment were added to the upper chamber as a positive control. In order to express the direct role of VEGF on the invasion of $\mathrm{C} 4-2 \mathrm{~B}$ cells, the recombinant human VEGF as a chemoattractant was added to the lower chamber. VEGF induced $\mathrm{C} 4-2 \mathrm{~B}$ cells to invade through the Marigel. In the absence of VEGF, the invasion was very low. With $100 \mu \mathrm{g} / \mathrm{ml}$ of bevacizumab in the upper chamber, significantly less numbers of $\mathrm{C} 4-2 \mathrm{~B}$ cells migrated into the lower chamber, and IgG1 did not inhibit the invasion (Figure $4 \mathrm{a}$ and $\mathrm{b}$ ). The result of the fluorescence microplate reader showed that the fluoresence intensity in the chamber with bevacizumab $(100 \mu \mathrm{g} / \mathrm{mL})$ was significantly lower than that in the chamber with control IgG1 (Figure 4c). Bevacizumab was high significantly decreased $\mathrm{C} 4-2 \mathrm{~B}$ cell invasion, comparing with control IgG (Figure $4, \mathrm{P}<0.01$ )

\section{Discussion}

In solid tumor, such as prostate cancer, there is the chance that the cancer will become advanced and spread to the bone. In prostate cancer, the most common site of a recurrence is the bone. In fact, approximately $80 \%$ of prostate cancer recurrences are in the bone [6]. If the cancer metastasizes to distant sites, the 5-year survival rate is the only $31 \%$. Importantly, once tumors metastasize to bone, they are virtually incurable and result in significant disease morbidity prior to a patient's death. Bone metastases can lead to pain, pathological fractures, nerve compression syndromes, and hypercalcemia. Current treatments are mainly palliative. Despite the high incidence and serious consequences of skeletal metastasis of prostate cancer, the mechanism underlying this osteotropism is unclear. However, it is clear that VEGF has been implicated in various carcinogenesis and metastasis as well as in angiogenesis.
VEGF is expressed by prostate cancer at a high level [7-9], and its expression correlates with increasing grade, vascularity, and tumorigenicity $[9,10]$. These relationships have been observed in human as well as in animal models of prostate cancer. High VEGF levels in prostate cancer are associated with poor prognosis. In addition, VEGF produced by tumor cells affects bone remodeling and might, therefore, facilitate nesting of metastatic cells in bone [11]. Bevacizumab is a recombinant, humanized monoclonal antibody that inhibits the binding of vascular endothelial growth factor (VEGF) to its receptors. Several experimental studies have examined the extent to which VEGF inhibitors or VEGF targeted agents prevent tumor cell growth and metastasis in vitro and in vivo [12-20]. In this study, we focus on the effect of bevacizumab on human bone metastatic LNCaP-derivative $\mathrm{C} 4-2 \mathrm{~B}$ prostate cancer cell line.

Angiogenesis is one of the critical events required in the cancer metastatic process. VEGF is a specific stimulator of vascular endothelial cell proliferation and tumor angiogenesis. VEGF is produced in response to various cellular and environmental stimuli. VEGF is overexpressed in many human neoplasms $[4,5,7,9,20-22]$. This expression is associated with increased tumor size, necrosis and tumor angiogensis. New blood vessels that grow within the tumor secondary to VEGF expression are structurally and functionally irregular, as they exhibit dead ends, disordered blood flow, and increased permeability. These irregularities in blood flow lead to further tumor hypoxia and subsequent increases in VEGF production [23,24]. In this study, we confirm that human bone metastatic prostate cancer cell line C4-2B has a higher level of VEGF than its parental cell line LNCaP, although both of cell lines have high levels of VEGF expression. We found that VEGF production significantly increased 6-fold when bone metastatic prostate cancer cells were cocultured with vascular endothelium.

VEGF exhibits the effects on the growth and progression of neoplasia. Several studies have shown a correlation 

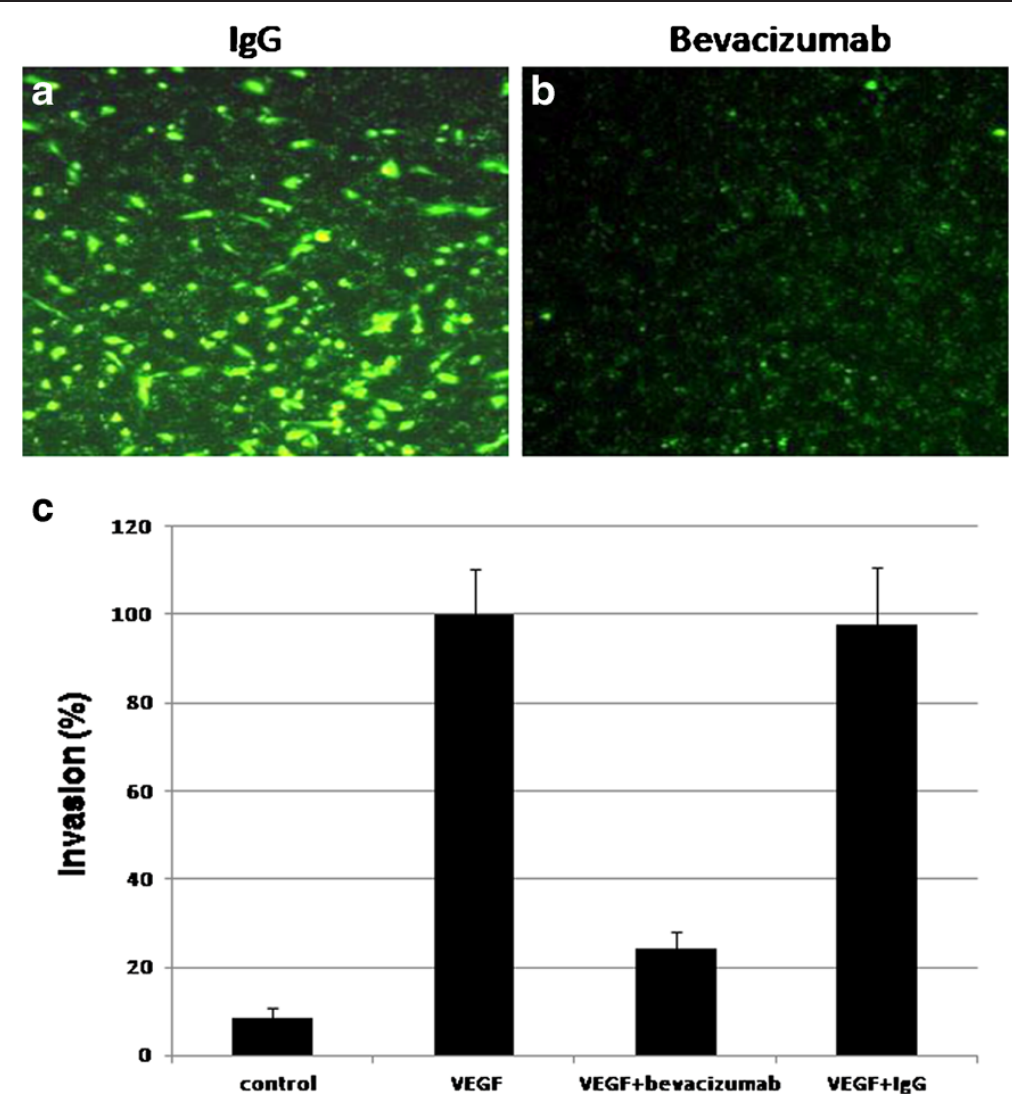

Figure 4 Bevacizumab reduced the ability of invasion in C4-2B (b), comparing with an equal amount of IgG treatment (a). In the invasion assay, we seeded cells on the top of the Matrigel and added VEGF to the lower chamber. Invasive cells penetrate Matrigel and end up on the other side of the Matrigel. We estimated invasion by measuring the fluoresence intensity in the fluorescence microplate reader and counting the number of invading cells, and setting the average of invading cell numbers of C4-2B with VEGF added to the lower chamber as $100 \%$. The results showed that VEGF-mediated invasion of C4-2B was suppressed by bevacizumab, and not by lgG1. ( $P<0.01$, Figure $4 \mathrm{C})$.

between increased VEGF expression and tumor growth [16-23]. Recent studies have indicated that bevacizumab treatment results in a dose-dependent inhibition of tumor growth in vitro and in vivo $[18,24,25]$. In our study, bevacizumab gave a dose-dependent and time-dependent reduction of cell proliferation in human bone metastatic prostate cancer cells.

Metastasis is an extraordinarily complex process. To successfully colonize a secondary site a cancer cell must complete a sequential series of steps before it becomes a clinically detectable lesion. These steps typically include separation from the primary tumor, invasion through surrounding tissues and basement membranes, entry and survival in the circulation, and arrest in a distant target organ. These are usually, but not always, followed by extravasation into the surrounding tissue, survival in the foreign microenvironment, proliferation, and induction of angiogenesis. The treatment against any steps may affect the formation of metastasis. Our results show bevacizumab significantly decreases the ability of invasion and angiogenesis formation in human bone metastatic prostate cancer cells.

\section{Conclusions}

In conclusion, anti-VEGF therapy has an inhibitory effect on human bone metastatic prostate cancer cells. Neutralization of VEGF disturbs the multistep process of metastasis including proliferation, angiogenesis and invasion. Anti-VEGF therapy is a potential adjuvant treatment strategy for the treatment of human bone metastatic cancer.

\section{Abbreviations}

VEGF, Vascular endothelial growth factor; bFGF, Basic fibroblast growth factor; IL-8, Interleukin 8; ELISA, Enzyme-linked immunosorbent assay.

\section{Competing interests}

All authors declare there are no competing interests.

\section{Authors' contributions}

LY and SY carried out the experiments. LY, SY, CZ and YC participated in study design and statistical analysis. LY, KV and YC drafted the manuscript. All authors read and approved the final manuscript. 


\section{Author details}

${ }^{1}$ Department of Orthopedics, the Third Xiangya Hospital of Central South University, Changsha, Hunan 410013, China. 'Department of Endocrinology, the Second Xiangya Hospital of Central South University, Changsha, Hunan 410011, China. ${ }^{3}$ School of Medicine, University of Pittsburgh, Pittsburgh, PA 15261, USA. ${ }^{4}$ Cancer Research Institute of Xiangya School of Medicine,

Central South University, Changsha, Hunan 410078, China.

Received: 4 January 2012 Accepted: 12 April 2012

Published: 1 May 2012

\section{References}

1. Ossowski L, Aguirre-Ghiso JA: Dormancy of metastatic melanoma. Pigment Cell Melanoma Res 2010, 23:41-65.

2. Al-Mehdi AB, Tozawa K, Fisher AB, Shientag L, Lee A, Muschel RJ: Intravascular origin of metastasis from the proliferation of endothelium-attached tumor cells: a new model for metastasis. Nat Med 2000, 6:100-102.

3. Vinothini G, Aravindraja C, Chitrathara K, Nagini S: Correlation of matrix metalloproteinases and their inhibitors with hypoxia and angiogenesis in premenopausal patients with adenocarcinoma of the breast. ClinBiochem 2011, 44:969-74

4. Wang Q, Diao X, Sun J, Chen Z: Regulation of VEGF, MMP-9 and metastasis by CXCR4 in a prostate cancer cell line. Cell Biology International 2011, 35:897-904.

5. Quaranta M, Daniele A, Coviello M, Venneri MT, Abbate I, Caringella ME, Di Tardo S, Divella R, Trerotoli P, Di Gennaro M, Schittulli F, Fransvea E, Giannelli G: MMP-2, MMP-9, VEGF and CA 15.3 in breast cancer. Anticancer Res 2007, 27:3693-600.

6. Bubendorf L, Schopfer A, Wangner U, Sauter G, Moch H, Willi N, Gasser TC, Mihatsch MJ: Metastatic patterns of prostate cancer: an autopsy study of 1,589 patients. Hum Pathol 2000, 31:578-583.

7. Ferrer FA, Miller $L$, Andrawis RI, Kurtzman SH, Albertsen PC, Laudone VP, Kreutzer DL: Vascular endothelial growth factor (VEGF) expression in human prostate cancer: in situ and in vitro expression of VEGF by human prostate cancer cells. J Urol 1997, 157(6):2329-33.

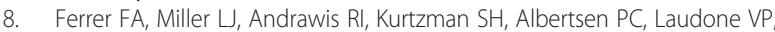
Kreutzer DL: Angiogenesis and prostate cancer: in vivo and in vitro expression of angiogenesis factors by prostate cancer cells. Urology 1998, 51(1):161-7

9. Ferrer FA, Miller $L$, Lindquist $R$, Kowalczyk $P$, Laudone VP, Albertsen PC, Kreutzer DL: Expression of vascular endothelial growth factor receptors in human prostate cancer. Urology 1999, 54(3):567-72.

10. Weidner N, Carroll PR, Flax J, Blumenfeld W, Folkman J: Tumor angiogenesis correlates with metastasis in invasive prostate carcinoma. Am. J. Pathol. 1993, 143(2):401-9.

11. Gerber HP, Vu TH, Ryan AM, Kowalski J, Werb Z, Ferrara N: VEGF couples hypertrophic cartilage remodeling, ossification and angiogenesis during endochondral bone formation. Nat Med 1999, 5(6):623-8.

12. Idfarb SB, Hudis C, Dickler MN: Bevacizumab in metastatic breast cancer: when may it be used? Ther Adv Med Oncol 2011, 3(2):85-93.

13. Di Costanzo F, Mazzoni F, Micol Mela M, Antonuzzo L, Checcacci D, Saggese M, Di Costanzo F: Bevacizumab in non-small cell lung cancer. Drugs 2008, 68(6):737-46.

14. deGramont A, Van Cutsem E: Investigating the potential of bevacizumab in other indications: metastatic renal cell, non-small cell lung, pancreatic and breast cancer. Oncology 2005, 69(suppl 3):46-56.

15. Amselem L, Cervera E, Díaz-Llopis M, Montero J, Garcia-Pous M, Udaondo P, García-Delpech S, Salom D: Intravitreal bevacizumab (Avastin) for choroidal metastasis secondary to breast carcinoma: short-term followup. Eye 2007, 21(4):566-567.

16. Zondor SD, Medina PJ: Bevacizumab: an angiogenesis inhibitor with efficacy in colorectal and other malignancies. Ann Pharmacother 2004, 38 (7-8):1258-1264

17. Brekken R, Overholser J, Stastny V, Waltenberger J, Minna JD, Thorpe PE: Selective inhibition of vascular endothelial growth factor (VEGF) receptor 2 (KDR/Flk-2) activity by a monoclonal anti-VEGF antibody blocks tumor growth in mice. Cancer Res 2000, 60(18):5117-5124.

18. Yang $H$, Jager MJ, Grossniklaus HE: Bevacizumab suppression of establishment of micrometastases in experimental ocular melanoma. Invest Ophthalmol Vis Sci 2010, 51(6):2835-42.
19. Zhang W, Ran S, Sambade M, Huang X, Thorpe PE: A monoclonal antibody that blocks VEGF binding to VEGFR2 (KDR/Flk-1) inhibits vascular expression of Flk-1 and tumor growth in an orthotopic human breast cancer model. Angiogenesis 2002, 5(1-2):35-44.

20. Sheidow TG, Hooper PL, Crukley C, Young J, Heathcote JG: Expression of vascular endothelial growth factor in uveal melanoma and its correlation with metastasis. Br J Ophthalmol 2000, 84(7):750-756.

21. Boyd SR, Tan D, Bunce C, Gittos A, Neale MH, Hungerford JL, Charnock-Jones S, Cree IA: Vascular endothelial growth factor is elevated in ocular fluids of eyes harbouringuveal melanoma: identification of a potential therapeutic window. Br J Ophthalmol 2002, 86(4):448-452.

22. Crosby MB, Yang H, Gao W, Zhang L, Grossniklaus HE: Serum vascular endothelial growth factor (VEGF) levels correlate with number and location of micrometastases in a murine model of uveal melanoma. $\mathrm{Br} \mathrm{J}$ Ophthalmol 2011, 95(1):112-7.

23. Shweiki D, Itin A, Soffer D, Keshet E: Vascular endothelial growth factor induced by hypoxia may mediate hypoxia-initiated angiogenesis. Nature 1992, 359(6398):843-845.

24. Claffey KP, Robinson GS: Regulation of VEGF/VPF expression in tumor cells: consequences for tumor growth and metastasis. Cancer Metastasis Rev 1996, 15(2):165-176.

25. Gerber HP, Ferrara N: Pharmacology and pharmacodynamics of bevacizumab as monotherapy or in combination with cytotoxic therapy in preclinical studies. Cancer Res 2005, 65(3):671-680.

doi:10.1186/1756-9966-31-40

Cite this article as: Yang et al:: In vitro the behaviors of metastasis with suppression of VEGF in human bone metastatic LNCaP-derivative C4-2B prostate cancer cell line. Journal of Experimental \& Clinical Cancer Research $201231: 40$

\section{Submit your next manuscript to BioMed Central and take full advantage of:}

- Convenient online submission

- Thorough peer review

- No space constraints or color figure charges

- Immediate publication on acceptance

- Inclusion in PubMed, CAS, Scopus and Google Scholar

- Research which is freely available for redistribution 